\title{
Phenomenological approaches to personal identity
}

\author{
Jakub Čapek ${ }^{1}$ (1) $\cdot$ Sophie Loidolt ${ }^{2}$
}

Accepted: 22 November 2020 / Published online: 9 February 2021

(C) Faculty of Arts, Charles University under exclusive licence to Springer Nature B.V. 2021

\begin{abstract}
This special issue addresses the debate on personal identity from a phenomenological viewpoint, especially contemporary phenomenological research on selfhood. In the introduction, we first offer a brief survey of the various classic questions related to personal identity according to Locke's initial proposal and sketch out key concepts and distinctions of the debate that came after Locke. We then characterize the types of approach represented by post-Hegelian, German and French philosophies of the nineteenth and twentieth centuries. We argue that whereas the Anglophone debates on personal identity were initially formed by the persistence question and the characterization question, the "Continental" tradition included remarkably intense debates on the individual or the self as being unique or "concrete," deeply temporal and-as claimed by some philosophers, like Sartre and Foucault - unable to have any identity, if not one externally imposed. We describe the Continental line of thinking about the "self" as a reply and an adjustment to the postLockean "personal identity" question (as suggested by thinkers such as MacIntyre, Ricœur and Taylor). These observations constitute the backdrop for our presentation of phenomenological approaches to personal identity. These approaches run along three lines: (a) debates on the layers of the self, starting from embodiment and the minimal self and running all the way to the full-fledged concept of person; (b) questions of temporal becoming, change and stability, as illustrated, for instance, by aging or transformative life-experiences; and (c) the constitution of identity in the social, institutional, and normative space. The introduction thus establishes a structure for locating and connecting the different contributions in our special issue, which, as an ensemble, represent a strong and differentiated contribution to the debate on personal identity from a phenomenological perspective.
\end{abstract}

Jakub Čapek

jakub.capek@ff.cuni.cz

Sophie Loidolt

sophie.loidolt@tu-darmstadt.de

1 Department of Philosophy and Religious Studies, Faculty of Arts, Charles University, nám. J.

Palacha 2, 11638 Prague 1, Czech Republic

2 Department of Philosophy, TU Darmstadt, Karolinenplatz 5, 64289 Darmstadt, Germany 
Keywords Phenomenology $\cdot$ Selfhood $\cdot$ Embodiment $\cdot$ Personal identity $\cdot$ Ipseity $\cdot$ Social identity · Edmund Husserl · Maurice Merleau-Ponty · Martin Heidegger · Jean-Paul Sartre · Hannah Arendt · Michel Foucault · Frantz Fanon · Paul Ricœur · Charles Taylor · Alasdair MacIntyre

This special issue addresses the debate on personal identity from a phenomenological viewpoint and especially from the angle of contemporary phenomenological research on selfhood. It engages with the question "Who am I?" as a question that concerns my identity as a person. This question can be asked as a question of re-identification ("Am I to be identified with this or that person in the old snapshot?"), as a question of characterization ("What are the essential characteristics of myself?"), as a question of belonging ("Which group or community am I a member of/do I identify with and why?") and, finally, as a question of individuation ("Am I really unique or just like everybody else?"). All four questions have already been addressed, up to certain extent, by phenomenological inquiries into selfhood, including aspects of temporality, narrativity, embodiment, sociality, and normativity. With the collected papers in this special issue, we intend to explicitly bring out the original approach to questions of personal identity, which can be developed through these phenomenological categories of analysis.

\section{The debate on personal identity and the self}

\subsection{Personal identity: Central questions, concepts, and criteria}

The debate on personal identity has a long history, reaching back to the classical chapter "Of Identity and Diversity" in John Locke's Essay Concerning Human Understanding (Locke 1975, Book II, Chap. XXVII). As is well known, Locke focuses on the so-called "persistence question" in these passages. In the wake of Locke, discussions of personal identity were therefore often framed by one decisive question: What are the necessary and sufficient conditions for a person at time $t 1$ to be the same as a person at time $\mathrm{t} 2$ ? As important and influential this question has proven to be, it is also clear that there is more to say about personal identity beyond the "persistence" and "reidentification" of a person across time. Another central question about personal identity, for example, concerns the individual characteristics of a person. When we are interested in "who one is," we are not simply trying to confirm the numerical identity of a person across time, but are interested in the characteristic features that make someone the particular individual he or she is.

Numerical identity, the concept aimed at by the re-identification question, has at times been taken to be synonymous with the absence of change. David Hume famously defined the idea of "identity or sameness," stating: "We have a distinct idea of an object, that remains invariable and uninterrupted through a supposed variation of time" (Hume 1978, Book I, IV, sect. 6). But for a person to remain the same in the sense of remaining numerically identical, what is required is the continuity of existence - and that does not rule out qualitative change. Depending on the view one takes, this continuity is located in the continuity of either the bodily or the mental existence of 
the person (see Noonan 2003, 2ff.). In both cases, this can, indeed must, accommodate specific forms of change, such as the processes of growing, getting older, and acquiring new experiences and losing certain memories. Yet, even if the persistence question allows for change to take place, the tricky follow-up question remains: What is it that persists? If we look at the "characterization question" of "who one is," the situation shifts to a different level, that of properties and characteristics. We then identify "a person as essentially the person she is, such that if those characteristics were changed, she would be a significantly different person, though she might be differentiated and reidentified as the same" (Rorty 1976, 2). Even though the questions of "sameness" and "change" remain, they refer to different concerns and result in different statements. To give but one example, the question of re-identification can be settled only by a yes or no answer. There are no degrees of sameness here. When answering the characterization question, by contrast, it is absolutely possible to state that someone is more or less the same person he or she used to be.

This shows that debates on personal identity revolve around certain central concepts such as change, persistence, constancy, and "becoming other." And these need careful clarification, also with respect to the questions we ask. What counts as "being the same" and "being other" varies depending on whether we ask the re-identification question or the characterization question (Schechtman 1996), and whether we are interested in the numerical or the qualitative identity of a person. Apart from these two classic concepts of "identity" (the numerical identity and the qualitative identity of a person), the concept of identity, when related to persons, can be given yet two other meanings. When applied to race, gender, class, ethnicity, nation and so forth, it either refers, when used in the first person, to personal self-identification with a group, or, when used in the third person (and always somewhat problematic), addresses conditions an individual must fulfill in order to count as a member of a certain class of persons (Crone 2017). In this sense, identity is something that different persons can share. As Sen (2006, xii) puts it, "we shift our attention from the notion of being identical with oneself to that of sharing an identity with others." Finally, identity can also refer to the uniqueness of a person, that is, not only someone's identity through time or someone's constant characteristics (which one can share with others) but someone's distinctiveness with respect to all other persons. In this latter context, the question of identity can be synonymous with the problem of individuation (Rorty 1976, 2). Certainly, these four meanings of the concept "personal identity" - numerical identity, qualitative identity, shared identity, and individuated identity - are often interrelated. But it helps to distinguish them carefully in each case, in order to understand properly what a particular account of "personal identity" actually claims.

The question of personal identity often leads to a quest for criteria of identity. This applies above all when we are interested in the re-identification question, which depends on a person's uninterrupted continuity of existence. Hence, it is not enough just to assume a continuity between different stages of a person's existence, including a continuity of his or her movement in time and space, or a continuity in changes of his or her features. It must be stated more precisely how we are to confirm or invalidate this assumption. What counts as a "criterion" in a strict sense thus refers to different conceptions of continuity of existence: the "bodily criterion," on the one hand, pertains to "some relation of physical continuity" (the continuous existence of the same body or brain matter); the "psychological criterion," on the other hand, denotes some relation of 
"psychological continuity" (for example, continuity of mental states, overlapping memories; see Noonan 2003, 2-6). The related debates often revolve around these two main criteria. Nevertheless, once we admit that "personal identity" can be understood in at least the four different meanings we have seen here, we should also adjust our notion of what can serve as a criterion of identity. Bodily and psychological continuity are most probably not enough then, and should be accompanied, as far as shared identity is concerned, by "self-identification with a group" and "categorization of oneself by others" (Brubaker, Cooper, 2000, 15; also Jenkins 2008, 42-43). The concept of criteria for personal identity thereby acquires a profoundly social and political tone. And finally, once we understand a person's identity as his or her individuality or unicity, it will no longer suffice to say that we are individuated only by our place in time and space, or by the external, social classification, but also by something additional. In the philosophical line of thinking explored in this volume, this necessary additional feature is often identified as the way we relate to ourselves. Thus, self-understanding enters the picture as well and becomes a relevant criterion of identity, especially if we are to conceive of the entities in question as persons. ${ }^{1}$

\subsection{Identity, self, and time: The continental perspective}

Whereas the Anglophone debates on personal identity were initially formed by the persistence question and the characterization question, post-Hegelian, German and French philosophies of the nineteenth and twentieth centuries included remarkably intense debates on the individual or the self as being unique or "concrete." Consequently, the universal and structural notion of personhood, as it appears in Kant, became individualized and concretized into the more Existenz-philosophical notion of selfhood, without having to appeal to a substance like the "individual soul" as is done in medieval conceptions of unique personhood (cf. Moran 2017). Instead, the relation of the "person qua self" to time stood in the foreground - which clearly also has ramifications for questions of personal identity. Both Kierkegaard (1992) and Heidegger (1993) devoted considerable effort to questions such as "What is it to be a self?" and "How does a self relate to time?" What we encounter here can usefully be labeled a deep temporalization of the self, be it in the form of the Heideggerian emphasis on the temporality of Dasein, in the Kierkegaardian analysis of the self as a synthesis of time and eternity, or in the Bergsonian idea of the profound self that precludes any kind of identity across time (Bergson 2013).

Yet, to complicate matters, thinkers such as Heidegger and Sartre categorically refused to associate the concept of identity with the human self. Instead, they opposed identity to ipseity (Selbstsein, ipséité): human beings are not "identical" ("the same"), they are, or can be, themselves (Heidegger 1993, §64). Paul Ricœur (1990) grasped this idea retrospectively by separating idem-identity and ipse-identity or "sameness" and "selfhood." Still the question remains of how this emphasis on the temporalized self transforms the traditional question of personal identity? One thing is undoubtedly

\footnotetext{
1 "To ask what a person is, in abstraction from his or her self-interpretations, is to ask a fundamentally misguided question, one to which there couldn't in principle be an answer" (Taylor 1989, 34). In this volume, Katja Crone refers to the concept of self-understanding ("the way people conceive of themselves") in order to make clear whether and how transformative experiences can be qualified as changing the identity of a person (Crone 2021).
} 
central: if the time of the self is understood as lived or experienced time, then it is no longer the measurable, objective time in which two different points, $t 1$ and $t 2$, are compared and identified as two "slices" of the same person. The time of the self, by contrast, is the time of personal becoming, of finding or losing oneself; it is the time of a unique life that is co-determined by the individual, but is also shaped by others; it is the time that can be told in a story; and so forth.

Since at least the 1980s, several attempts have been made to understand the "Continental" line of thinking about the "self" as a reply to the post-Lockean "personal identity" question. Among the attempts to bring together these two conceptually different traditions of thought, we would like to mention those by Charles Taylor (especially 1989), MacIntyre (2007), Paul Ricœur (1990), and David Carr (1986). MacIntyre, for example, does not seek to provide a novel answer to the question of personal identity. Instead, he emphasizes the context without which the very question remains meaningless. He claims that no account of personal identity can stand alone, since "all attempts to elucidate the notion of personal identity independently of and in isolation from the notions of narrative, intelligibility and accountability are bound to fail" (MacIntyre, 2007, 218). Ricœur attempts to do something similar when reconstructing the conceptual framework within which the question of personal identity can properly be asked. This framework combines some elements of action theory (including the concept of agent and the reasons for an action) with some core distinctions of philosophical ethics. For both Ricœur and MacIntyre, the question of personal identity presupposes an Aristotelian, teleological ethics, or, to put it differently, the ethical concept of aiming at a good life (MacIntyre, 2007, chap. 15; Ricœur 1990, 202-10; Atkins 2008). To be "one," to have a life that has a unity, is hence interpreted in terms of a teleological horizon of all the particular activities and experiences of the person in question. In this sense, personal unity entails normative aspects. A more Kantian account, resulting in similar normative commitment-structures to achieve personal identity, is provided by Christine Korsgaard (2003).

These ethical accounts of personal identity have been criticized in various ways: either as confounding the question of identity with the question of personal integrity, or as prioritizing a unified life at the expense of an episodic life for no good reason (Strawson 2004), or as downplaying the otherness in our experience. László Tengelyi (2004), to take but one example, resolutely rejects the ethical concern for unity as obfuscating different sorts of alterity - be it the alterity of the other or the alterity in myself, that is, the otherness of my body or my subconscious. And these are by far not the only types of rejection of the question of personal identity. The normative assumption of personal unity being preferable to disintegration has been famously questioned by Michel Foucault in his Archeology of Knowledge: "Do not ask who I am and do not ask me to remain the same: leave it to our bureaucrats and our police to see that our papers are in order" (Foucault 2002). ${ }^{2}$ In this quotation, the reidentification question is clearly associated with the police, bureaucrats and "their morality." For Althusser, Foucault, as well as for Agamben, the question of "Who am I?" or "Who are you?" is necessarily connected with the process of subjection and subjectification of individuals,

\footnotetext{
${ }^{2}$ Judith Butler contends that the very question of identity may imply a form of ethical violence. The individual can, and maybe even should, refuse to answer the question "Who are you?". What merits attention is not the question, but the situations in which it is raised, the "scenes of address" (Butler 2005).
} 
including the process of their reduction to a socially identifiable appearance (Agamben 1996, 74-80). Persons - in the sense of being diachronically identical or coherent in their lives - are hence primarily taken to be products of an omnipresent normative structure. To be sure, with Foucault, Derrida, Butler, Agamben et al. we find ourselves in a philosophical landscape quite different from the one inhabited by Locke, Parfit, and MacIntyre. What matters for such a dissident, post-structuralist perspective is the attempt to uncover and understand the omnipresent, yet dynamic logic of identity which forces subjects to be identical across time. At the same time, it is Foucault (1984) himself who in his late years closely examined the practices of a "care for the self' in order to develop a critical aesthetics of existence. These and similar discussions show that a contemporary inquiry into personal identity cannot ignore the normative dimensions of the question, including their criticism.

\section{Personal identity in phenomenology}

Twentieth-century phenomenologists have made major contributions to the investigation of the self which can be fruitful for reformulating questions of personal identity. Edmund Husserl provides us with analyses of consciousness, the lifeworld, subjectivity and intersubjectivity, which, taken together, form a suitable context for both theoretical and practical questions concerning the identity, unity, and uniqueness of selves and persons (the latter are explicitly tackled in his late writings on ethics). These concepts can be usefully developed towards a comprehensive phenomenological account of personal identity which also engages with the classical Lockean questions and takes them to a new level (see Jacobs 2010). Heidegger, for his part, has decisively shaped the debate by differentiating between the "who" and the "what," as well as by delivering a fundamentally temporal conception of the self. ${ }^{3}$ But this is certainly not all that the phenomenological tradition has to offer for rephrasing the question of personal identity by means of an analysis of the self. Sartre examined affective states such as shame, hate, and love combined with a phenomenological and existential version of the struggle for recognition; Levinas conceived of identity as an ethical substitution for the other; and Arendt can legitimately be understood as a phenomenologist who regards action and public appearance as being central to "who one is."

Yet, as inspiring as these approaches to the self might be, the question remains whether they articulate a coherent account of persons and their identity. Is phenomenology to be associated with one particular theory of personal identity? At first glance, some phenomenological theories seem to offer a variant of the psychological (mental) approach, especially Husserl's approach, which locates the correlation of consciousness and world as well as the self-weaving stream of time-consciousness at the heart of phenomenological analyses. Other phenomenological works come close to the bodily approach, such as Merleau-Ponty who in his Phenomenology of Perception analyzes the experience of one's own body. Thomas Fuchs (2016), for example, draws on

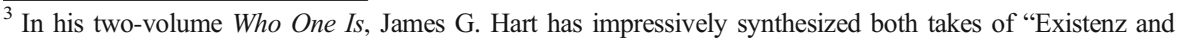
Transcendental Phenomenology" on personhood and the self (Hart 2009).
} 
Merleau-Ponty when claiming that personal identity is based on the experienced diachronic unity of bodily existence. ${ }^{4}$ Heidegger, again, neither appeals to psychological continuity nor to feeling of somatic constancy, but takes the "care structure" to be constitutive of human existence or Dasein. He thus embraces the idea that identity is "practical" (as in Korsgaard), and that it consists in the self being "an issue for itself," as has been defended by Steven Crowell (2013). So it seems that phenomenology offers a colorful package of different ideas on the human self's being in time. But this should not obscure the fact that it also represents a certain kind of philosophical investigation, as we will argue in what follows.

First of all, it can be convincingly shown that phenomenology does not share certain assumptions often present in the debate on personal identity as a reidentified numerical identity across time: (a) the idea of time as a succession and (b) a third-person, quasineutral description of the facts pertaining to personal identity in "impersonal terms" (Parfit 2003). ${ }^{5}$ None of this is shared by phenomenology: time is not reducible to an observed succession, and the being of a person is not to be described adequately from an impersonal "view from nowhere." Phrased in positive terms, it is fair to say that if personal identity is not something observed and re-identified, it is something that we experience or, more precisely, something persistent in the way we experience. In his Ideas II Husserl puts it as follows:

a person has, in the broadest sense, a typical character and properties of character. Everything a person lives through enlarges the framework of his pregivenesses [...] even without the memory, it determines the future content of lived experience [...] The person is formed through "experience" (Husserl 1989, 283, orig. Husserl 1952, 271).

This suggests a complex link between what we experience and who we are. The identity of a person is co-determined by what he or she has gone through and how. It is thus correlational, worldly, and imbued not only with first-person views but also second-person encounters and formative we-experiences, norms, and traditions of the intersubjective world. It is a unique style that is intrinsically linked with its Umwelt and hence also open and dynamic.

Having sketched here the shared framework of phenomenological debates on personal identity, we will now spell out three sets of observations in more detail, including the inner-phenomenological debates that take place within this shared framework. The following observations concern (2.1) layers of the self and embodied existence, (2.2) time and world, and (2.3) sociality and identity-all crucial domains for the phenomenological analysis of personal identity. This will, we hope, show that, as Merleau-Ponty (2014, lxxi) has famously claimed, phenomenology's "identity" is that of a certain "style" of philosophizing that is recognizable even in disagreement. We want to claim that it runs along the following lines in questions of personal identity.

\footnotetext{
${ }^{4}$ More precisely, he claims that personal identity rests on the bodily conditioned "pre-reflective feeling of sameness or a felt constancy of subjectivity" (Fuchs 2016).

${ }^{5}$ For an instructive phenomenological critique of the "impersonal description", see Paul Ricœur (Ricœur 1992, 129-39) or Steven Crowell in this volume (Crowell 2021).
} 


\subsection{Phenomenological debates on layers of the self and embodied existence}

The crucial starting point for a phenomenological approach to personal identity is the concept of the self. What are the special features of such a phenomenological concept? It has often been claimed by phenomenologists that the self has an intrinsic or necessary relation to the experience it undergoes, without necessarily being an explicit content of this experience. Experiences have the structural feature that they are mine. The question is, however, whether we may understand this constant presence of the "self" in experience as the identity of the same self. And what is this "self" that seems to make part of all my experiences? Classic, Husserlian phenomenology answers these questions by establishing a distinction between the "pure ego" and the "personal self." This line of thinking is represented in our volume especially by John Drummond, who develops the distinction between "self-identity" and "personal identity", each of them characterized by a particular type of individuation and different criteria of identity (Drummond 2021). The "self" or the "pure ego" (something like a "first self") in this Husserlian approach is not a personal "me," but a formal structure of all experiences, and it is only the personal, as it were, "second" self that is a concrete individual, a person with its unique bodily or character features, convictions and other individualizing traits. As a result, we arrive at a multilayered account of personal identity. This raises the obvious question: which self guarantees diachronic identity? Should both or all selves have some kind of diachronic existence, or is one of them more basic than the other(s)?

At some points in his work, Husserl attributes strict diachronic identity to the pure ego, not to the concrete person. As we read, for instance, in First Philosophy (1923/24), the pure ego has "absolute identity"; it is a "numerically identical subjective pole of all my conceivable experiences." And Husserl immediately adds that this ego is different from the "well known person" that we - each of us - know from our experience of ourselves. ${ }^{6}$ The duality of the pure ego and the concrete person, however, poses a challenging problem. On the one hand, we cannot say anything particular about the pure ego, apart from its being the numerically identical subject pole of all our experiences. On the other hand, the different characteristics of a concrete person do not seem to provide a sufficient explanation of what makes him or her one and the same across time.

The duality of the "pure ego" and the "personal self" resurfaces in contemporary phenomenological discussions of the self. In Dan Zahavi's Self and Other, the term "pure ego" is explained as the "formal and empty kind of individuation, one that characterizes every other possible subject," whereas the "personal ego" denotes the "person with abilities, dispositions, habits, interests, character traits, and convictions" (Zahavi 2014, 83-84). Hanne Jacobs (2010) makes a similar claim in her paper on

\footnotetext{
6 "Certainly, this I in its absolute identity creates problems. One used to identify it with the well-known person, the I, whom I know through my experience of life. But it cannot be asserted that there is an absolute evidence of character traits which would determine personal reality. Having said that, is it not quite correct of Descartes to claim the strongest of all evidences for the pure ego as that of the pure cogito? It is certainly not an empty or even a metaphysical substruction, even though I can predicate nearly nothing about it in absolute evidence, except that as an undetachable and numerically identical subject pole it belongs to all my possible experiences. But clearly not as a part; each part of a lived experience disappears with itself and no new lived experience can have a part truly identical to the previous one." (Husserl 1956, 104-105).
} 
Husserl and personal identity. She also reinvokes the distinction of the "personal I" and the "formal I" when separating "personal identity" from "formal identity" respectively. It is on the basis of some personal features having undergone change that I can say that my personal identity has changed. And it is on the basis of the formal identity that I can say that these were $m y$ features. According to Jacobs, I can thus become another person while still being the same formal "I" (Jacobs 2010, 350-52). The difficult question is however: what is the nature of this formal I ("pure ego," "minimal self," and so forth) and what kind of diachronic identity does it have? If it is not a pure Kantian form (which ultimately also causes problems for a phenomenological approach) but rather an "experiential first-person perspective," as Zahavi proposes, does this "minimal self" (Zahavi 2014) possess a strong identity across time? It is surely not deprived of a certain diachronic dimension, such as the capacity to retain the recent past and anticipate the near future. But is this enough for "personal identity"?

Intensive discussions on the "minimal self" (including a whole range of psychopathological investigations) and a Husserl-inspired layers-of-self model, as Zahavi has proposed, together represent one of the most important strands of how debates on personal identity can usefully be framed today in contemporary phenomenology. To avoid the rather Kantian and static notion of the formal self while keeping the transcendental take on the topic, Wolfgang Fasching in this volume proposes to understand the "I" as an abiding "dimension" which does not change, even though the content of our experience changes (Fasching 2021). On the other hand, even if we accept the self-person distinction, we can legitimately criticize the different accounts of the self as too formal or even empty. According to Crowell (2021, in this volume), concepts such as the "minimal self," the "formal I," and the self as an abiding "dimension" or a "featureless ego" describe a very general structure of experience, but not the self. They all leave out a fundamental aspect of the self: the fact that it is an issue for itself, that "its own identity matters." The self, according to Crowell, comes into existence by answering the call of conscience which enjoins it "to take over being a ground" (Crowell 2021). Against this Heideggerian move, Hanne Jacobs (2021) argues in our special issue that an account of the self as commitment is offered already in Husserl's descriptions of egoic experience as attentive experience. The self is therefore not only self-aware but also active; and this activity, for human wakeful conscious experience, happens in socio-historical embeddedness.

Some phenomenological authors, however, avoid the self-person distinction. For instance, Jean-Paul Sartre, in an early work, La transcendence de l'ego (Sartre 1962), argues that the only conceivable self is the concrete, individual person. For Sartre, however, this is clearly an object of experience. He also claims that no "ego" is required for an experience. Like the very early Husserl of the Logical Investigations, Sartre seems to suggest that the stream of consciousness weaves its unity by itself without needing an egoic pole. Merleau-Ponty, Patočka and Gurwitsch head in similar directions when speaking of the "anonymity" of consciousness, on the basis of which different versions of self/I/ego are gradually established. The question of "identity" is thus again treated using the layer model, except now the" lowest" level is an anonymous, self-weaving unity. But what happens with the first-person perspective on this level? Is it, for example, a lived and experienced unity or an "unconscious" one? This and similar questions need to be tackled if a discussion of personal identity is to be developed on the basis of these positions. 
Another, certainly more popular option is to regard the constitution of the person as a practical activity (as mentioned above). In this case, the personal I arises from our everyday comportment and continually grasps and shapes itself in its individual decisions. We have already pointed to Heidegger and Crowell's related interpretation, which comes close to ideas defended by Christine Korsgaard (Korsgaard 2003, Crowell 2013, chap. 11). But Husserl's ethics also allow us to view personal identity, unlike the identity of the ego, as, in fact, a normative task and achievement (Loidolt 2021, Drummond 2021). To take another example, Ricœur argues in his early work Freedom and Nature, that every decision constitutes the identity of the person, because the decision implies that the one who decides and the one who is bound by the decision, constitute one and the same person (Ricœur 1966, 55-62). This emphasis on activity and on ethically relevant agency as forming a constitutive part of the concept of the person is an important contribution that contemporary phenomenology has made to accounts of personal identity.

It is, however, not the only way to underline the concrete character of the person and his or her identity (in contrast to the transcendental, abstract or "pure" character). Below the level of ethics and agency, there are, as many phenomenologists argue, more primordial layers of personhood, especially the lived body. If the body is part of someone's identity, it is not understood as one body among others (as a Körper in Husserl), but as one's own body, as a lived body (what Husserl calls the Leib). As both Husserl and Merleau-Ponty have abundantly shown, the "mineness" of the body is experienced and experientially established in a complex set of interrelated tactile and affective sensations that are inseparable from our capacity to move our body. Persons are always bodily beings. If they are identical across time, it is in part because their bodies possess a certain diachronic dimension (a "body memory"; Fuchs 2018). This does not mean that phenomenology embraces the bodily or somatic criterion of personal identity. The diachronic identity of a lived body is still an experienced identity, and consists, for instance, in bodily habits which are far deeper than memories understood as conscious recollections. Even though the memory of the body cannot sufficiently account for it, the identity of a person is inconceivable without the former (Čapek 2019).

It is fair, to put it briefly, to claim in general that phenomenology understands the person as embodied and active. Yet the question remains whether this idea of the person presupposes a more basic self, be it an experiential unity (first-personal or anonymous) or a "formal" unity. Discussions of this question still stand in the foreground of contemporary research and are therefore present in several essays of our special issue.

\subsection{Personal identity, time, and world}

The question of personal identity, as many philosophers from Locke to Parfit understand it, implies a concept of time which prioritizes the idea of succession. According to phenomenological analyses of time, be it in Husserl, Heidegger, or Merleau-Ponty, our experience of time is, however, not reducible to a succession that we only record (Ricœur 1985, 56): we anticipate upcoming events, and we remember some past events. In all of this, we are well aware of the "flow of time," and yet we understand the anticipated as well as the remembered episodes as forming part of our present or as 
being at least related to it. When I live through my present day in the joyful expectation that I will see one of my loved ones in the evening, I allow both anticipation and memory to shape my present experience. Consequently, if it is true that we are not only "in" time, but that we are capable of "having" a present, then time is not, or not only, a succession of events. Time is a succession that is grasped or summarized from the point of view of a particular present. Or, to put in terms of the famous McTaggart distinction, time is inconceivable without the past-present-future distinction (A-series), which is irreducible to the earlier-later distinction (B-series; McTaggart 1908). To be sure, past events are replaced by present ones, and time implies their succession. And yet the past is always the past for someone who lives in the present and relates to the past event as being no longer present. These temporal distinctions, for example, the present-past distinction, thus exist for someone. Time implies a self.

Moreover, temporal distinctions have their "objective" side: what elapses in time constitutes a certain unity that is not reducible to a succession of phases, for instance, a melody, a movement in space, or a qualitative change (say, the setting of the sun). Here, particular phases are understood in the light of the unity of what Husserl calls the "temporal object" and its duration. Consequently, we understand what has just happened, say the beginning of the sunset, not as a dead past, cut-off from the present. The past, the present, and the coming phases (of a melody, movement, or change) receive their meaning or intelligibility from some larger temporal unity.

In addition, the attention we pay, for example, to a melody (to a movement or a qualitative change we follow) modifies our own being in time: there is not only the temporal unity of the melody, but also the temporal unity of our own listening to that melody. Both the melody we hear and our hearing of the melody are temporally extended and can be regarded as two different kinds of diachronic unity. ${ }^{7}$

These diachronic unities do not have to be "personal" if that should mean they are characteristic of an individual human being. Most people in a concert hall "have" the same kind of temporally extended "object" (the composition performed), and may even have a similar experience of it. This example cannot therefore account for the identity of a person. But it does show at least that there are some diachronic unities that arise in our experience correlatively to what we experience, and that there is a mutual exchange between me and what I experience in establishing unities across time.

It is precisely this idea of correlation, of the mutual relation between the temporal unity of an object and the temporal unity of my experience, which is explored in some contemporary phenomenological approaches. When Hanne Jacobs, for example, again in her paper on personal identity, comments on the Lockean problem of personal continuity through sleep, she claims that the identity of myself is not established merely by my recollection of past experiences, but also by my capacity to experience the same world as the familiar place of my life. This capacity to experience the same familiar world rests not on some explicit acts of my mind (remembering memories), but on my habitualized ways to perceive and move: "our persistence through sleep does not merely consist in a relation of the (present) self to the (past) self, but shows itself in the experience of the one familiar world, an experience that arises because our passive habitualities bear on every new current intentional directedness" (Jacobs 2010, 342).

\footnotetext{
${ }^{7}$ In his lectures on time consciousness, Husserl distinguishes between the "perception of the duration" and the "duration of the perception" (Husserl 1966, 22).
} 
Thus, on a certain level, the unity of the self through time cannot be explained without referring to the unity of the world experienced (see also Jacobson 2015). This sheds light on the question of the discontinuity of the self. While continuity consists in habitually relating to the same familiar world, the discontinuity in question here does not reside in the lack of consciousness (as emphasized by the traditional, Lockean examples of sleep, hallucination, or other altered states of mind), but in the discontinuity of the way I experience the world, that is, in the "absence of a familiarity with the world I was previously so familiar with" (Jacobs 2010, 343).

From these observations we draw two conclusions. First, when attempting to understand the diachronic unity of a person, phenomenology does not refer to the reidentified numerical identity or continuity. This is because reidentified numerical oneness presupposes (a) the idea of time as a succession and (b) a third-person or impersonal view of phenomena relevant to someone's identity (be they mental states, as in Parfit, or continued bodily existence, as in the somatic approach). For phenomenology, by contrast, my past life-stage is not a past "time-slice" to be joined to my present "time-slice." Rather, it is a past for me, my own past. In his Self and Other, Dan Zahavi phrases this refusal as follows:

How can it [the self], so to speak, survive a period of nonexistence? I am not sure these questions are well posed, however. They assume that the proper way to approach the question regarding experiential diachronicity is from a third-person perspective. They think of the stream of consciousness in analogy with a cord, and compare the dreamless sleep with a cutting of the cord. (Zahavi 2014, 72). ${ }^{8}$

Time is not to be reduced to a succession of events comparable to a cord or a flow. It is, as we have seen, a succession grasped by someone from a certain present according to the past-present-future distinction. Diachronic unity, if it exists, may be analyzed from within this temporal experience. The same holds true for diachronic difference, whether in the everyday form of falling asleep or in the form of substantial changes (unprecedented events, or transformative experiences; see Crone in this volume). What we can confidently conclude from the brief mention of phenomenological approaches to time and self is that the question of personal identity in phenomenology implies a certain shift in, or adjustment to, the very question: the person or the self is not something observed and re-identified; if there is an identity to person or self, it is something we experience or, more precisely, something in the way we experience.

This leads to the second point we wish to make, that is, the first-person approach does not imply that personal unity (or diversity) is merely a subjective matter. Instead, personal unity (or diversity) arises out of a correlation with what the self or the person experiences. For example, there is no diachronic unity of a personal habit without a

\footnotetext{
${ }^{8}$ Zahavi goes on to say: "But if we instead adopt a first-person perspective, which supposedly is the perspective an experience-based approach should adopt, the situation looks rather different. From the firstperson perspective, it is not as if one has to reach back and establish a connection to a separate stream of consciousness. Although there is certainly something it is like to fall asleep and to wake up, there is in dreamless sleep no first-personal absence of a first-person perspective [...]. There are no extended periods of unconsciousness, and linking up with an experience you had yesterday, say, an acute experience of shame or embarrassment, is no different from linking up with an experience you had earlier this morning. In both cases, we are faced with a diachronically unified consciousness" (Zahavi 2014, 73).
} 
familiar surrounding world of this habit; and if someone undergoes a change of identity (in a sense to be specified), this is obviously also related to what he or she faces, experiences, and undergoes. Events such as a serious illness or the loss of a loved one have an impact on our personal identity. Hence, both personal continuity and personal change must be understood against the background of the world, its stability and events.

The analysis of aging provides concrete evidence that personal identity and change are inseparably connected to one's experience of the surrounding world. In his contribution to this special issue, Christian Sternad even argues that this is why the social aspect of aging has priority: "it is first and foremost my contact with others and the world, through which I come to a reflection on myself" (Sternad 2021). Here is also where phenomenological accounts of psychopathology and personal identity often take their point of departure. Philipp Schmidt and Thomas Fuchs, who cover this aspect in our issue, explore the dispersal of identity in borderline personality disorder, relating to worldly un/familiarity as well as to narrativity disruption (Schmidt and Fuchs 2021). Yet episodes of disruption can of course just as well occur in a "normal life" and can even be events that form an "identity." Consequently, unprecedented, uncanny, and unknown experiences have to be integrated into reflections on personal identity. One particular strain of contemporary phenomenology called the "phenomenology of the event" (Maldiney, Romano) puts forward the radical claim that it is precisely the encounter with the unprecedented that constitutes a person's identity. Claude Romano, a key proponent of this line of thought, defines selfhood as the "capacity for a renewal in light of what happens to us" and he consequently makes it "inseparable from the phenomenon of transformation" (Romano 2014, 24 and 198). Conceptually, a person's identity is understood here not as numerical, qualitative, or shared identity, but as uniqueness.

The concept of the unexpected event also plays a major role in the grand strands of narrativity theory and its phenomenological versions. From Arendt to Ricœur to Carr, "time and narrativity" are core phenomenological features of personal identity. Lifechanging events can be retrospectively incorporated into a story and personal time can acquire the structure of a story of a life. It is somewhat disputable whether personally experienced time already contains this narrative structure at the most basic level or if the act of storytelling actually unifies and forms lived experiences into "episodes" and finally into what we properly call a story (for a brief survey, see Čapek 2017). If it holds true that life is a story, it is definitely a story that cannot be anticipated: "the stories, the results of action and speech, reveal an agent, but this agent is not an author or producer" (Arendt 1981, 184). For Arendt, my identity, my story, is not something I produce like a book where I am the sovereign author over my work; rather, much depends on worldly events, on others, and on their reaction to my deeds. Clearly, then, the openness in which my story and personal identity unfold is not only intrinsically structured by lived time and correlated to the world, but is also socially determined.

\subsection{Sociality and identity}

Given the previous observations, phenomenological accounts are well equipped to address the social and institutional aspects of personal identity. Institutions and others confirm or endanger our continuity as persons. This happens in private contexts, as well as in the form of social roles, and even on the more - seemingly — abstract level of legal 
status. Such confirmation and endangerment are not simply exterior ascriptions to a ready-made, untouchable identity, but often concern the very core of "who I am" in complex interrelations between individuals, groups, and institutions. These interrelations take place in the forms of struggle, recognition, and conflict, or on the level of shared emotions, values, and activities. As David Carr (2021) argues in this volume, "our personal identity is not something that exists independently of our social interactions and commitments. Our social world gives us our identity, or it is that world from which we choose our identity. Personal identity is social identity." Hence, the background from which distinct identities emerge is a net or fabric woven of narratives, symbols, norms, and histories, through which individuals experience themselves and others, as well as their bonds to those others.

Consequently, what comes into focus when thinking about social identity is not so much reflections on the continuity of consciousness or the continuous somatic existence of a person, but rather the political and social struggles or experiences of sharing, group formation and identification. It is also not so much about the ethical commitments that are typical of a normative account of personal identity, as it is about power, violence, freedom and agency, as well as feelings of belonging or alienation and practices of inclusion and exclusion, which all constitute important components in the formation of a person's identity.

In her article in this special issue Tereza Matějčková reminds us that this conflictual and social aspect is a central legacy of Hegelian philosophy and could also be fruitfully employed in accounts of personal identity connected to narrativity and sociality. Against Ricœur's insistence on the coherence of a life narrative, she therefore argues that the moment of becoming and enacting one's selfhood can also lie precisely in interrupting narrativity, in saying "no" to a story concerning myself and therefore consciously forming my identity (Matějčková 2021). Given its strong Hegelian and Marxist influences, French existential phenomenology has contributed extensively to these conflictual and essentially social workings of personal identity: Beauvoir, Fanon, Sartre or Merleau-Ponty are therefore frequently taken up in the theoretical context of "identity politics" of today.

But other strands in phenomenology with less Hegelian influence also address the question of "who one is" in a social and political perspective. While Heidegger portrays the dissociation from "the They" (das Man) as playing a decisive role in becoming oneself, Arendt sees interaction with others, appearing before them, and the narratives that are socially and politically formed, as constitutive of "who I am" (Loidolt 2019). Earlier phenomenologists had already emphasized the importance of community for becoming a person (Husserl, Scheler, Stein). And it is Husserl (1973, 170-171; Husserl 1952, 319) himself who claims that persons could only come into being through social interaction-which allows for ramifications regarding the continuous identity of persons in social interaction, and thus takes us back to discussions about layers of the self.

In current debates, many of these questions are treated in the context of weintentionality, social ontology, and shared emotions. What does it mean to experience and identify as "we"? What are the conditions under which I consider myself as belonging to a certain community? How do I come to view others through that, as co-members or as alien to my group (Zahavi 2019; Szanto and Moran 2015; León/ 
Szanto/Zahavi 2019; Thonhauser 2018)? Furthermore, these social commitments are often deeply felt, as Carr notes in his article of this volume, and are "a source of often courageous and risky action." Both questions of social ontology concerning the constitutive relations of the self and concerning the "you-me-we-and-them" constellations are asked here, as well as more emotional questions of how "membership" and ingroup/ outgroup mechanisms determine a relationship to myself, my identity, and my agency.

In addition, these existentialist inquiries often have another important aspect at the heart of their theories: the question of personal freedom vs. suppressive-but sometimes also productive ${ }^{9}$ - social normativity. Sartre (1992) is therefore skeptical about social roles or any other self-objectifications being sources of identity construction. He regards them as ultimately driven by bad faith and the "useless desire" to have the stability of an "in-itself." At the same time, Sartre is well aware that we are identified by the look of others and therefore live in a constant struggle of what they see and what we are or rather what we are not, given our self-projecting, free nature. The body and the emotion of shame play a central role in these analyses.

This paves the way for a completely new articulation of how racist identification works. It is through the look of others, through alienation based on the "epidermal scheme," as Frantz Fanon (1986) cogently puts it, that a person gets "racialized." Fanon not only brings out the political impact of this constellation, but also demonstrates the deep consequences for personal identity qua social identity and its pathologies in racist societies. Furthermore, the "epidermal scheme" makes more than clear that social identity is not only formed on a linguistic, narrative or symbolic level, but also inscribes itself directly in and onto the body. Another central author elaborating on this existentialist take on identity is Simone de Beauvoir (2011). Her careful identification of the different components operating in the formation of "gender-identity" avant la lettre and its lived experience has, like Fanon's work, provided us with rich theoretical tools for critical inquiries. In both cases it is clear that becoming aware of the operation and history of one's social identity (as racialized and gendered), not only gives rise to interesting theoretical insights but essentially politicizes the situation, as Marx conceived it in his discussion of rising class consciousness.

In the current debate, this topic of identity formations concerning race, class, age, gender and their intersectionality are taken up by the new strands of "political phenomenology" (Herrmann und Bedorf 2019) and "critical phenomenology," which often have not only a theoretical but also a clear political agenda, precisely in the sense of a "struggle for liberation" (Guenther 2020, and, more generally, the volume edited by Weiss et al., 2020). This has also intensified discussions and collaborations between scholars working with approaches from phenomenology, critical theory, and poststructuralism. Maren Wehrle (2021) and Scott Marratto (2021) each give an example of these discussions in our special issue, with a focus on personal identity. Wehrle interprets Butler's theory of performativity and materialization as a theory of identity and elaborates on the important contribution that phenomenology can make with the concept of "habit formation," where the relations between passive habitualization and active endorsement of personal (gendered) identities can be reexamined already on the level of the body. Scott Marratto engages in a debate with Foucauldian approaches to identity formation and argues for a Merleau-Ponty-inspired

\footnotetext{
${ }^{9}$ We are referring here to Michel Foucault's "productive" notion of power and norms (see Foucault 1981).
} 
account of "identity as institution" which also allows to think creative agency within institutionalized power structures.

All in all, it is fair to say that phenomenology has continuously evolved in its engagement with these questions of social identity and the politicization of this identity, by adopting as well as by reinventing its classic tools. While Marratto's proposal that we view the "phenomenological subject not as a constituting subject, but as an instituted/instituting subject" illustrates the latter, Wehrle's return to Husserl's concepts of habitualization and sedimentation exemplifies the former. In this way, we can see how the new application and reinterpretation of phenomenological concepts and ways of thinking, from Iris Marion Young to Sara Ahmed, can be made fruitful for questions of personal identity, as well as for "queering" this identity.

Becoming who one is (genetically), having to be someone (normatively) and being "orientated" in spaces accordingly, and finally, being (made) able to choose (in practice) who one is and to which community one wants to belong to, are intrinsically social and political matters. They inscribe themselves into all levels of the human being - and are therefore questions that phenomenology can and must treat in theoretical, constitutional, institutional, socio-ontological, and critical analyses.

\section{The special issue}

According to the three domains we have singled out as crucial for phenomenological analysis of personal identity - (2.1) layers of the self and embodied existence, (2.2) time and world, and (2.3) sociality and identity — we have arranged the papers in three groups: “Group One: I, Self, Person” (Drummond, Fasching, Crowell, Jacobs), “Group Two: Change, Stability, and Becoming Other" (Crone, Sternad, Schmidt and Fuchs), and "Group Three: Society, Institutions, Normativity" (Carr, Matějčková, Wehrle, Marratto). Certainly, all these papers may also be read as pieces of original research in themselves and independently of one another. But our aim is to view and present them as a structured ensemble that gives a diverse yet representative overview of what phenomenology has to offer in the current debates on personal identity.

Funding This article is a part of a research program funded by the Czech Science Foundation (Project "Personal Identity at the Crossroads: Phenomenological, Genealogical, and Hegelian Perspectives," GACR 18-16622S). The completion and the publication of this work was supported by the European Regional Development Fund project "Creativity and Adaptability as Conditions of the Success of Europe in an Interrelated World” (reg. no.: CZ.02.1.01/0.0/0.0/16 019/0000734).

Open Access This article is licensed under a Creative Commons Attribution 4.0 International License, which permits use, sharing, adaptation, distribution and reproduction in any medium or format, as long as you give appropriate credit to the original author(s) and the source, provide a link to the Creative Commons licence, and indicate if changes were made. The images or other third party material in this article are included in the article's Creative Commons licence, unless indicated otherwise in a credit line to the material. If material is not included in the article's Creative Commons licence and your intended use is not permitted by statutory regulation or exceeds the permitted use, you will need to obtain permission directly from the copyright holder. To view a copy of this licence, visit http://creativecommons.org/licenses/by/4.0/. 


\section{References}

Agamben, G. (1996). Mezzi senza fine: Note sulla politica. Torino: Bollati Boringhieri.

Arendt, H. (1981). The human condition. Chicago: University of Chicago Press.

Atkins, K. (2008). Narrative identity and moral identity: A practical perspective. New York: Routledge.

de Beauvoir, Simone. 2011. The Second Sex. Transl. by C. Borde and S. Malovany-Chevallier, s.1., Vintage Publishing.

Bergson, H. (2013). Essai sur les données immédiates de la conscience. Paris: PUF.

Brubaker, R., \& Cooper, F. (2000). Beyond identity. Theory and Society, 29, 1-47.

Butler, J. (2005). Giving an account of oneself. New York: Fordham University Press.

Čapek, J. (2017). Narrative identity and phenomenology. Continental Philosophy Review, 50(3), 359-375.

Čapek, J. (2019). Personal identity and the otherness of One's own body. Continental Philosophy Review, 52(3), 265-277.

Carr, D. (1986). Time, narrative, and history. Bloomington/Indianapolis: Indiana University Press.

Carr, David. 2021. "Personal identity is social identity", Phenomenology and the Cognitive Science (this volume).

Crone, K. (2017). "Personale Identität," in Handbuch der Metaphysik, edited by Markus Schrenk, Stuttgart: Metzler.

Crone, Katja. 2021. "Personal identity, transformative experiences, and the future self," Phenomenology and the Cognitive Science (this volume).

Crowell, S. (2013). Normativity and Phenomenology in Husserl and Heidegger. Cambridge. Cambridge University Press.

Crowell, S. (2021). "On what matters: Personal identity as a phenomenological problem," Phenomenology and the Cognitive Science (this volume).

Drummond, J. (2021). "Self-identity and personal identity," Phenomenology and the Cognitive Science (this volume).

Fanon, F. (1986). Black Skin, White Masks. Transl. By C. Markmann, London: Pluto Press.

Fasching, W. (2021). "The I: A dimensional account," Phenomenology and the Cognitive Science (this volume).

Foucault, M. (1981). "The Order of Discourse," in Untying the Text. A Post-Structuralist Reader. Edited and introduced by Robert Young. Boston/London: Routledge, 48-78.

Foucault, M. (1984). Histoire de la sexualité III: Le souci de soi. Paris: Gallimard.

Foucault, M. (2002). The archeology of knowledge. New York: Routledge.

Fuchs, T. (2016). Self across time: The diachronic Unity of bodily existence. Phenomenology and Cognitive Science, 16, 291-315. https://doi.org/10.1007/s11097-015-9449-4.

Fuchs, T. (2018). Leiblichkeit und personale Identität in der Demenz. Deutsche Zeitschrift für Philosophie, $66(1), 48-61$.

Guenther, L. (2020). Critical phenomenology. In G. Weiss, A. V. Murphy, \& G. Salomon (Eds.), 50 concepts for a critical phenomenology (pp. 11-16). Evanston: Northwestern University Press.

Hart, J.G. (2009). Who one is. Book I and II. Dordrecht: Springer.

Heidegger, M. (1993). Sein und Zeit. Tübingen: Niemeyer.

Herrmann, S., \& Bedorf, T. (Eds.). (2019). Political phenomenology: Experience, ontology, episteme. London: Routledge.

Husserl, E. (1952). Ideen zu einer reinen Phänomenologie und phänomenologischen Philosophie II: Phänomenologische Untersuchungen zur Konstitution. Haag: Nijhoff (Husserliana, Vol. IV).

Husserl, E. (1956). Erste Philosophie (1923/24). Erster Teil. Haag: Nijhoff (Husserliana, Vol. VII).

Husserl, E. (1989). Ideas II, transl. By R. Rojcewicz and a. Schuwer, Dordrecht: Kluwer.

Husserl, E. (1966). Vorlesungen zur Phänomenologie des inneren Zeitbewußtseins. Haag: Nijhoff (Husserliana, Vol. X).

Husserl, E. (1973). Zur Phänomenologie der Intersubjektivität. Zweiter Teil: 1921-1928. Haag: Nijhoff (Husserliana, Vol. XIV).

Jacobs, H. (2010) "Towards a phenomenological account of personal identity," in Philosophy, phenomenology, sciences: Essays in commemoration of Edmund Husserl. Edited by Carlo Ierna, Hanne Jacobs, and Filip Mattens, Phaenomenologica 200, Dordrecht/Heidelberg/London/New York: Springer, 333-61.

Jacobs, Hanne. 2021. "Husserl, the active self, and commitment", Phenomenology and the Cognitive Science (this volume).

Jacobson, K. (2015). "The Gift of Memory: Sheltering the I," in D. Morris, K. MacLaren (eds.), Time, Memory, Institution. Merleau-Ponty's New Ontology of Self, Athens: Ohio University Press, 29-42. 
Jenkins, Richard. 2008. Social identity, 3rd. edition. New York: Routledge.

Kierkegaard, S. (1992). Krankheit zum Tode. Gütersloh: Gütersloher Verlag.

Korsgaard, C. M. (2003). Personal identity and the Unity of agency: A Kantian response to Parfit. In R. Martin \& J. Barresi (Eds.), Personal identity (pp. 168-183). Oxford: Blackwell.

León, F., Szanto, T., \& Zahavi, D. (2019). Emotional sharing and the extended mind. Synthese, 196, 48474867. https://doi.org/10.1007/s11229-017-1351-x.

Locke, J. (1975). An essay concerning human understanding. Oxford: Oxford University Press.

Loidolt, S. (2019). 'Who one is' - A political issue? Hannah Arendt on personhood, maximal self, and bare life. In T. Bedorf \& S. Herrmann (Eds.), Political phenomenology: Experience, ontology, episteme (pp. 165-192). London/New York: Routledge.

Loidolt, S. (2021). Husserl on personhood and practical agency. In H. Jacobs (Ed.), The Husserlian mind. New York Routledge: The Routledge Philosophical Minds Series.

MacIntyre, A. (2007). After virtue: A study in moral theory. Chicago: Notre Dame University Press, 3rd edition.

Matějčková, T. (2021). "Saying No (to a Story): Personal Identity and Negativity," Phenomenology and the Cognitive Science (this volume).

McTaggart, J. M. E. (1908). “The unreality of time,” Mind, New Series, no. 68, 457-74.

Marratto, S. (2021). "Identity as institution: Power, agency, and the self", Phenomenology and the Cognitive Science (this volume).

Merleau-Ponty, M. (2014). Phenomenology of Perception. Transl. By D. a. Landes, London/New York: Routledge.

Moran, D. (2017). "The Phenomenology of the Person: Husserl, Scheler, Stein," manuscript of a talk given at SPEP. Memphis, October 20, 2017.

Parfit, D. (2003). "Why Our Identity Is Not What Matters," in R. Martin and J. Barresi (eds.), Personal Identity, Oxford: Blackwell, pp. 115-143 (reprint of essential passages from Reasons and Persons, Oxford 1986, chaps. 10-12).

Ricœur, P. (1966). Freedom and Nature: The Voluntary and The Involuntary. Transl. By E. Kohák, Evanston: Northwestern University Press.

Ricour, P. (1992). Oneself as another. Chicago: University of Chicago Press.

Romano, C. (2014). Event and Time. Trans. By S. E. Lewis, New York: Fordham University press.

Rorty, A. O. (Ed.). (1976). The identities of persons. Berkley, Los Angeles, London: University of California Press.

Ricour, P. (1990). Soi-même comme un autre. Paris: Seuil.

Ricour, P. (1985). Temps et récit 3: Le temps raconté. Paris: Seuil.

Sartre, Jean-Paul. (1992). Being and Nothingness. Trans. By H. Barnes, New York: Washington Square press.

Schechtman, M. (1996). The constitution of selves. Ithaca: Cornell University Press.

Schmidt, P., Fuchs, T. (2021). "The unbearable dispersal of being: Narrativity and personal identity in borderline personality disorder", Phenomenology and the Cognitive Science (this volume). Personality Disorder.

Sen, A. (2006). Identity and violence: The illusion of Destiny. New York/London: VERLAG.

Sternad, C. (2021). "When time becomes personal. Aging and personal identity," Phenomenology and the Cognitive Science (this volume).

Strawson, G. (2004). "Against Narrativity," in Ratio. An International Journal of Analytic Philosophy, Vol. 17/4, December 2004, 428-52.

Szanto, T., \& Moran, D. (Eds.). (2015). Phenomenology of sociality: Discovering the "we". New York: Routledge.

Taylor, C. (1989). The sources of the self: The making of the modern identity. Cambridge: Cambridge University Press.

Tengelyi, L. (2004). The wild region in life-history. Evanston: Northwestern University Press.

Thonhauser, G. (2018). Shared emotions and collective affective intentionality. I Quaderni della Ginestra, 22, $100-113$.

Wehrle, M. (2021). "'Bodies (that) matter': The role of habit formation for identity", Phenomenology and the Cognitive Science (this volume).

Weiss, G., Murphy, A. V., \& Gayle, S. (Eds.). (2020). 50 concepts for a critical phenomenology. Evanston: Northwestern University Press.

Zahavi, D. (2014). Self and other: Exploring subjectivity, empathy, and shame. Oxford: Oxford University Press.

Zahavi, D. (2019). Second-person engagement, self-alienation, and group-identification. Topoi, 38(1), 251-260.

Publisher's note Springer Nature remains neutral with regard to jurisdictional claims in published maps and institutional affiliations. 